\title{
Investigating the Provenance of Iron Artifacts of the Royal Iron Factory of São João de Ipanema by Hierarchical Cluster Analysis of EDS Microanalyses of Slag Inclusions
}

\author{
Elmer Antonio Mamani-Calcina ${ }^{a, b}$, Fernando José Gomes Landgraf ${ }^{a, c}$, Cesar Roberto de Farias Azevedo ${ }^{a *}$ \\ ${ }^{a}$ Department of Metallurgical and Materials Engineering, Escola Politécnica, Universidade de São \\ Paulo - USP, Av. Professor Mello Moraes, 2463, CEP 05508-030, São Paulo, SP, Brazil \\ ${ }^{b}$ Department of Materials Engineering, Universidad Nacional de San Agustin, Av. Venezuela $S / N, C P$ \\ 04.000, Arequipa, Peru \\ ${ }^{c}$ Institute for Technological Research of the State of São Paulo - IPT, Av. Prof. Almeida Prado, 532, \\ CEP 05508-901, São Paulo, SP, Brazil
}

Received: June 11, 2016; Revised: August 13, 2016; Accepted: September 8, 2016

\begin{abstract}
Microstructural characterization techniques, including EDX (Energy Dispersive X-ray Analysis) microanalyses, were used to investigate the slag inclusions in the microstructure of ferrous artifacts of the Royal Iron Factory of São João de Ipanema (first steel plant of Brazil, XIX century), the D. Pedro II Bridge (located in Bahia, assembled in XIX century and produced in Scotland) and the archaeological sites of São Miguel de Missões (Rio Grande do Sul, Brazil, production site of iron artifacts, the XVIII century) and Afonso Sardinha (São Paulo, Brazil production site of iron artifacts, XVI century). The microanalyses results of the main microconstituents of the microstructure of the slag inclusions were investigated by hierarchical cluster analysis and the dendrogram with the microanalyses results of the wüstite phase (using as critical variables the contents of $\mathrm{MnO}, \mathrm{MgO}, \mathrm{Al}_{2} \mathrm{O}_{3}, \mathrm{~V}_{2} \mathrm{O}_{5}$ and $\mathrm{TiO}_{2}$ ) allowed the identification of four clusters, which successfully represented the samples of the four investigated sites (Ipanema, Sardinha, Missões and Bahia). Finally, the comparatively low volumetric fraction of slag inclusions in the samples of Ipanema $(\sim 1 \%)$ suggested the existence of technological expertise at the ironmaking processing in the Royal Iron Factory of São João de Ipanema.
\end{abstract}

Keywords: Archaeometallurgy, Royal Iron Factory of São João de Ipanema, Microstructural characterization, Slag inclusions, Hierarchical cluster analysis

\section{Introduction}

This paper is a product of a research project focused on the Brazilian ironmaking history in the XIX century, from the point of view of the microstructural analysis of the slag inclusions found in iron objects. One of the objectives is to explore whether the Royal Iron Factory of São João de Ipanema was a place where an up-to-date engineering was effectively at work. The other objective is to develop a new methodology using the EDS microanalysis of the slag inclusions in order to group and separate the samples in accordance with their sources: the Royal Iron Factory of São João de Ipanema; the Archaeological site of Afonso Sardinha (State of São Paulo, Brazil), Archaeological site of São Miguel de Missões (State of Rio Grande do Sul, Brazil), and the Dom Pedro II Bridge (State of Bahia, Brazil, using iron imported from Scotland).

The Royal Iron Factory of São João de Ipanema was founded in 1810 in the city of Iperó (State of São Paulo, Brazil) and its blast furnaces began the production of pig iron in 1818 , being the only two blast furnaces in Brazil in operation up to $1888^{1-2}$. This factory produced thousands of tons of iron bars in its lifespan, initially with the process of direct process and, subsequently, exclusively with the indirect process (pig iron

* e-mail: c.azevedo@usp.br production in the blast furnace followed by refining) until $1926^{3}$. In a nearby site and using the same source of iron ore, a Portuguese explorer, Afonso Sardinha, had produced a few tons of iron in the late sixteenth century by direct process. This production spot, referred as Afonso Sardinha site, is considered to be the first exploration of the mine of magnetitic iron ore located in the Araçoiaba hill ${ }^{4}$. Some ferrous artifacts from this site were collected by an archaeologist from Museu Paulista, Dr. M. Andreatta, in $1983^{4}$. Additionally, iron objects were collected at several archaelogical sites of the Missões region, in Brazil, which were active in the XVIII century. It is still not certain whether these ferrous artifacts were produced ${ }^{5}$ from local iron ore or imported from Europe 5 . During XIX century, important structural components were usually imported from Europe, such as the iron parts of the Dom Pedro II Bridge, in the State of Bahia, which was built between 1882 and 1885 with elements brought from the United Kingdom ${ }^{6}$.

Ferrous products manufactured before the twentieth century contain much large amounts of slag inclusions in their microstructure, typically higher than $3 \%$ in volumetric fraction. These inclusions contain various oxides, which are related in terms of chemical composition to the whole production system. In this sense, the chemical composition of these slag inclusions is defined by the composition of 
the different materials and raw materials used during the manufacturing process, such as iron ore, charcoal ash, furnace lining, fuel, hearth lining, fluxes and etc. The investigation of the chemical composition of slag inclusions in ancient ferrous artifacts has been used to determine some technological and historical characteristics of the metallurgical processing, including their possible provenance ${ }^{7-16}$.

In 2007 Dillmann and L'Héritier ${ }^{7}$ presented a methodology applying data processing on the EDX microanalyses of slag inclusion of 170 ferrous objects sampled from several archaeological sites and monuments. They built bivariate graphs showing the contents of some oxides present in these inclusions (for instance, $\% \mathrm{SiO}_{2}$ versus $\% \mathrm{Al}_{2} \mathrm{O}_{3} ; \% \mathrm{CaO}$ versus $\% \mathrm{~K}_{2} \mathrm{O}$; and $\% \mathrm{MgO}$ versus $\% \mathrm{Al}_{2} \mathrm{O}_{3}$ ) and applied data filtering and linear regression (assuming the line passing through the origin) techniques to investigate the provenance of these objects. They determined the "signature" of each production site by using the values of the slope of the linear correlations of the various bivariate graphs. Additionally, they proposed another bivariate map featuring the oxide contents of the slag inclusions $\left(\% \mathrm{P}_{2} \mathrm{O}_{5}\right.$ versus $\left[\% \mathrm{Al}_{2} \mathrm{O}_{3}+\% \mathrm{MgO}+\%\right.$ $\left.\mathrm{K}_{2} \mathrm{O}\right] / \% \mathrm{FeO}$ ratio) to identify whether these ferrous objects had been produced by direct or indirect process.

In 2009 Blakelock et al. ${ }^{8}$ analyzed several specimens from bloom to forged products, which were produced by T. Young (Museum of Welsh Life, Wales Parents) between 1998 and $^{9} 2004$ from a series of ore reduction experiments. In these experiments, Young recreated the direct reduction and forging processes used by the prehistoric population near Cardiff to produce iron artefacts ${ }^{9}$. Additionally, the authors ${ }^{8}$ compared the chemical composition of the slag inclusions of ferrous artifacts from two different archaeological sites (X century, Jordan; and 900BC, Israel). They investigated and analyzed various bivariate graphs of the chemical compositions of the slag inclusions in order to establish their process signatures. The authors demonstrated that the use of these bivariate graphs was not precise to establish the signatures of the investigated processes - even for samples which were experimentally produced - due to the extensive number of processing variables interfering in the final chemical composition of the slag inclusions.

In 2009 Desaulty et al. ${ }^{10}$ examined few hypotheses about the origins of iron reinforcements, which were sampled from French medieval churches. They used the chemical analysis results of the major elements found in the slag inclusions along with the analyses of trace elements in order to investigate 32 ferrous artifacts from the cathedrals of Beauvais and Roven and 14 ferrous parts from archaeological sites near the Bray Pays region (located between the cities of Beauvais and Roven and famous for the production of iron by indirect process during the fifteenth century). Their results indicated that the trace elements could only be used to identify the provenance of ferrous artifacts produced by direct process. The authors rejected the hypothesis that the iron samples taken of the cathedrals of Beauvais and Roven had been produced in the Bray Pays region.

In 2012 Charlton et al. ${ }^{11}$ analyzed the same samples, investigated by Blakelock et al. ${ }^{4}$, but they applied a new methodology for analyzing the results of EDX microanalysis of the slag inclusions, using only the amounts of $\mathrm{Al}_{2} \mathrm{O}_{3}$, $\mathrm{SiO}_{2}, \mathrm{~K}_{2} \mathrm{O}, \mathrm{CaO}, \mathrm{TiO}_{2}$ and $\mathrm{MnO}$ in the slag inclusions. They used multivariate method and hierarchical clusters analysis in order to separate and identify the provenance within the production process (for instance, bloomery slag, fuel ash, clay or smithing flux) of the various slag inclusions found in the ferrous samples. They applied the same methodology to investigate the provenance of various ferrous artifacts from Scandinavia using previous results ${ }^{12}$ and the authors were able to successfully identify three clusters of samples, representing the production sites of Denmark, Norway and Sweden.

In 2014 Disser et al. ${ }^{13}$ investigated the slag inclusions of 60 ferrous pieces sampled from Gothic monuments of Beauvais Cathedral (Picardie, France) and Mutte Tower Metz Cathedral (Lorraine, France). They applied "logistic regression" to distinguish ferrous pieces produced by direct and indirect process and used the multivariate method to determine the signature of the production process of the artifacts collected in the French Gothic cathedrals.

Maia et al. ${ }^{14-16}$ investigated by EDX microanalysis the slag inclusions of ferrous objects collected from the Royal Iron Factory of São João de Ipanema and Afonso Sardinha archaeological site. The authors questioned the effectiveness of the linear regression method (passing through the origin), which had been proposed by Dillmann and L'Héritier ${ }^{7}$ to determine the signature of the production processes, but they did not investigate other methodologies ${ }^{10-11,13}$ to obtain the signature of the production processes of Ipanema and Sardinha. They suggested that the presence of higher contents of $\mathrm{TiO}_{2}$ in the inclusions was a typical characteristic of the artifacts collected in Sardinha's archaeological site.

The main purpose of the present investigation is to test a new methodology, which uses SEM microscopy and EDX microanalysis of the main microconstituents found in the microstructure of the slag inclusions (such as the "matrix" and the wüstite phase) - instead of merely using the average microanalysis of the "entire" multiphase inclusions ${ }^{11}$ - to correctly separate the ferrous artifacts of four different origins (Ipanema, Sardinha, Missões and Bahia) by hierarchical cluster analysis of these microanalysis results.

\section{Materials and methods}

\subsection{Samples}

The analyzed samples are part a collection of objects, which are currently stored in the Laboratory for Microstructural Characterization Hubertus Colpaert (Polytechnic School, 
University of São Paulo, Brazil). The identification and description of the samples used in the present investigation are shown in Table 1. The samples from the Royal Factory of São João de Ipanema were collected at the Geological Collection of the National Museum (Rio de Janeiro, Brazil) from iron bars, which the director of the Royal Factory, Colonel Mursa, had bestowed to the Brazilian Emperor, Dom Pedro II, in 1886. These artifacts were almost certainly produced using the Styrian refining method described by Ipanema's engineer, L. Dupré17.

The sample of Sardinha is one of the various ferrous artifacts collected around the ruins of a site about two kilometers from Ipanema factory, which were almost certainly produced by direct process ${ }^{4}$.

The sample of Missões comes from the archaeological site of São João Batista Mission, in Rio Grande do Sul, Brazil $1^{5}$. The Austrian Jesuit, Anton Sepp, described the furnaces which were constructed in the region of Missões to produce iron by direct process ${ }^{18}$, but there is still an uncertainty concerning the provenance of these ferrous artefacts $^{5}$ : were they produced from local iron ore or imported from Europe?

The sample of Bahia was collected around 2010 from a railroad bridge located (Dom Pedro II) in the State of Bahia, Brazil. The bridge was built in 1885 using iron plates with the brand "Mossend" stamped on them. Mossend Iron and Steel Works were one of the largest producers of malleable iron in Scotland during the second half of the XIX century ${ }^{19}$, operating with two different refining methods: the puddling process and the reverberatory furnace process.

\subsection{Microstructural characterization and EDX microanalysis}

Microstructural characterization was carried out using light and scanning electron microscopy. The volumetric fractions of the slag inclusions were obtained by the image analysis of the unetched metallographic samples of approximately 20 fields at 100X magnification under light microscope using Image-Pro Plus (Media Cybernetics) software.

The microanalyses of the multiphase inclusions were carried out on the main microstructural constituents of the inclusion (the "matrix" and the wüstite phase) and on an larger area representing the "entire" multiphase inclusion, in a total of 480 microanalyses (at least 60 regions of the slag inclusion were analyzed for each sample). The authors recognize that the "matrix" of the inclusions is multiphasic, but the microanalyses of these other phases were omitted in the present work. The authors used, instead, larger microanalysis areas to obtain the mean values of the chemical microanalysis of the "matrix" of the inclusions.

Microanalyses were carried out in a JEOL JSM-6300 scanning electron microscope equipped with a Noran EDX detector and using the following parameters: working distance of $15 \mathrm{~mm}$; voltage of $20 \mathrm{kV}$; acquisition time of 180 seconds; area mode; standardless mode; and ZAF correction. Additionally, a restriction for the quantitative chemical analyses was imposed by assuming that all the chemical elements present in the inclusions were in the form of oxides. These results generated various bivariate graphs, such as $\% \mathrm{SiO}_{2}$ versus $\% \mathrm{Al}_{2} \mathrm{O}_{3} ; \% \mathrm{CaO}$ versus

Table 1: Identification, description and origin of the investigated ferrous samples

\begin{tabular}{|c|c|c|c|}
\hline Sample & Origin & $\begin{array}{l}\text { Volume fraction } \\
\text { of slag inclusions }\end{array}$ & $\begin{array}{l}\text { Description of the objects and } \\
\text { dimensions }\end{array}$ \\
\hline Ip-130 & $\begin{array}{l}\text { Royal Iron Factory of São João de Ipanema (São Paulo, Brasil), } \\
\text { Geological Collection of the National Museum (Rio de Janeiro, Brazil) }\end{array}$ & $1.6 \pm 0.5$ & $\begin{array}{l}\text { Rectangular bar (cross section } \\
\text { of } 10 \times 4 \mathrm{~mm} \text { and length of } \\
100 \mathrm{~mm} \text { ) }\end{array}$ \\
\hline Ip-131 & $\begin{array}{l}\text { Royal Iron Factory of São João de Ipanema (São Paulo, Brasil), } \\
\text { Geological Collection of the National Museum (Rio de Janeiro, Brazil) }\end{array}$ & $1.2 \pm 0.4$ & $\begin{array}{l}\text { Round bar (diameter of } 8 \mathrm{~mm} \\
\text { and length of } 100 \mathrm{~mm} \text { ) }\end{array}$ \\
\hline Ip-133 & $\begin{array}{l}\text { Royal Iron Factory of São João de Ipanema (São Paulo, Brasil), } \\
\text { Geological Collection of the National Museum (Rio de Janeiro, Brazil) }\end{array}$ & $0.7 \pm 0.5$ & $\begin{array}{c}\text { Square bar (cross section of } \\
12 \times 12 \mathrm{~mm} \text { and length of } 100 \\
\mathrm{~mm})\end{array}$ \\
\hline Ip-134 & $\begin{array}{l}\text { Royal Iron Factory of São João de Ipanema (São Paulo, Brasil), } \\
\text { Geological Collection of the National Museum (Rio de Janeiro, Brazil) }\end{array}$ & $1.3 \pm 0.8$ & $\begin{array}{l}\text { Square bar (cross section of } \\
17 \times 17 \mathrm{~mm} \text { and length of } 100 \\
\mathrm{~mm} \text { ) }\end{array}$ \\
\hline Ip-135 & $\begin{array}{l}\text { Royal Iron Factory of São João de Ipanema (São Paulo, Brasil), } \\
\text { Geological Collection of the National Museum (Rio de Janeiro, Brazil) }\end{array}$ & $1.2 \pm 0.6$ & $\begin{array}{c}\text { Square bar (cross section of } \\
22 \times 22 \mathrm{~mm} \text { and length of } 100 \\
\mathrm{~mm})\end{array}$ \\
\hline B-145 & Dom Pedro II Bridge (Bahia, Brazil and produced in Scotland) & $6 \pm 2$ & $\begin{array}{l}\text { Sample of the bridge (plate of } \\
\text { approximately } 400 \times 200 \mathrm{~mm} \\
\text { and thickness of } \sim 20 \mathrm{~mm} \text { ) }\end{array}$ \\
\hline M-123 & Archaeological site of São Miguel de Missões (Rio Grande do Sul, Brazil) & $7 \pm 3$ & $\begin{array}{l}\text { Nail (larger cross section of } 3 \\
\text { x } 3 \mathrm{~mm} \text { and length of } 50 \mathrm{~mm} \text { ) }\end{array}$ \\
\hline S-107 & $\begin{array}{c}\text { Archaeological site of Afonso Sardinha (São Paulo, Brazil), Prof. } \\
\text { M. Andreatta's collection }\end{array}$ & $4 \pm 1$ & $\begin{array}{l}\text { Nail (larger cross section of } \\
15 \times 15 \mathrm{~mm} \text { and length of } 100 \\
\mathrm{~mm} \text { ) }\end{array}$ \\
\hline
\end{tabular}


$\% \mathrm{~K}_{2} \mathrm{O} ; \% \mathrm{Al}_{2} \mathrm{O}_{3}$ versus $\% \mathrm{MgO} ; \% \mathrm{FeO}$ versus $\% \mathrm{SiO}_{2}$; and $\% \mathrm{TiO}_{2}$ versus $\% \mathrm{~V}_{2} \mathrm{O}_{5}$. Extra care was taken in the numerical interpretation of $\mathrm{FeO}$ content found in the slag inclusions, as the depths of the inclusions were not precisely known and some "contribution" of Fe of the matrix could occur, slightly increasing the intensity of the Fe peaks during the EDX microanalyses of "thin" slag inclusions and, consequently, the amount of $\mathrm{FeO}$ in inclusions with a depth below $1 \mu \mathrm{m}$. Therefore, inclusions larger than $5 \mu \mathrm{m}$ were regularly selected for the EDX microanalyses.

\subsection{Hierarchical cluster analysis}

Multivariate method and hierarchical cluster analysis were applied using a critical set of variables for each type of microanalysis results: the entire multiphase inclusions, the matrix of the inclusions; and the wüstite phase of the inclusions. After data treatment, preliminary cluster analysis was applied to detect the outliers, which were excluded from the analysis so the critical sets of oxides could be identified for each type of microanalysis (entire multiphase inclusions, the matrix of the inclusions and the wüstite phase). Common transformations were then used to apply equal weights to the results within the critical sets of oxides, such as standardization and log-ratio transformations, and these results were grouped by the Ward method ${ }^{20}$. The parameter of similarity for the definition of clusters adopted in the present work was the Euclidean distance and the data was statistically analyzed by using version 1.16.03 Statgraphics Centurion XVI software (StatPoints Technologies Inc. 1982 - 2010). The results of the hierarchical cluster analysis method were displayed in dendrograms, which were used to identify four clusters. These clusters were analyzed in order to assess the efficacy of the grouping for each set of microanalysis results (entire multiphase inclusions, the matrix of the inclusions and the wüstite phase).

\section{Results}

Table 1 features the volumetric fraction of slag inclusions in all samples, which can be divided into two groups of results. The samples of Ipanema showed values near $1 \%$, while the remaining samples showed values of volumetric fraction of slag inclusions above $4 \%$.

Typical results of microstructural characterization of the slag inclusions are shown in Figures 1-a to 1-d. In general, these inclusions presented a complex microstructure with the presence of dendrites wustita $(\mathrm{FeO})$ in a multiphase matrix.

The average results of EDX microanalysis of the entire multiphase inclusions are shown in Table 2 for basic comparison, indicating high relative values for the standard deviation, as the chemical composition of each inclusion depends on its provenance within the production processing, such as bloomery smelting, bloom refining and artifact production; along with the chemical composition of the ore, furnace lining, fuels, fluxes and hearth lining ${ }^{8,11}$. All samples, however, featured $\mathrm{FeO}$ content above $60 \%$. The highest contents of $\mathrm{V}_{2} \mathrm{O}_{5}$ in the inclusions were found for the samples of Ipanema and Sardinha sites. The latter also presented inclusions with the highest contents of $\mathrm{MgO}, \mathrm{K}_{2} \mathrm{O}$ and $\mathrm{TiO}_{2}$, while the samples of Ipanema showed the highest contents of $\mathrm{P}_{2} \mathrm{O}_{5}$. Finally the sample of Missões presented inclusions with the highest content of $\mathrm{SiO}_{2}$ and the sample of Bahia presented the highest $\mathrm{MnO}$ content.

Four typical bivariate graphs $\left(\% \mathrm{SiO}_{2}\right.$ versus $\% \mathrm{Al}_{2} \mathrm{O}_{3}$; $\% \mathrm{CaO}$ versus $\% \mathrm{~K}_{2} \mathrm{O} ; \% \mathrm{Al}_{2} \mathrm{O}_{3}$ versus $\% \mathrm{MgO}$; and $\% \mathrm{FeO}$ versus $\% \mathrm{SiO}_{2}$ ) of the values of EDX microanalyses of the entire multiphase inclusions are shown in Figures 2-a to 2-d. These results featured the usual scattering, not allowing the accurate grouping of the samples by visual cluster analysis in accordance with their provenance, confirming previous results ${ }^{14-16}$. Figures $2-\mathrm{a}\left(\% \mathrm{SiO}_{2}\right.$ versus $\left.\% \mathrm{Al}_{2} \mathrm{O}_{3}\right)$ and $2-\mathrm{b}$ ( $\% \mathrm{CaO}$ versus $\% \mathrm{~K}_{2} \mathrm{O}$ ), for instance, showed the best results in terms of clustering, suggesting the existence of four distinct groups of results, which were in agreement with their provenance. Figure 2-c to 2-d, however, did now allow the correct identification of four distinct clusters.

Table 3 shows the average EDX microanalysis of the matrix of the microstructure of the slag inclusions for basic comparison. The matrix presented lower amounts of $\mathrm{FeO}$ (usually bellow $60 \%$ ) and lower standard deviations than those found for the entire multiphase inclusions (see Table 2). The samples of Ipanema, except for the IP- 135 sample, showed lower contents of $\mathrm{SiO}_{2}, \mathrm{~K}_{2} \mathrm{O}, \mathrm{Al}_{2} \mathrm{O}_{3}, \mathrm{MnO}, \mathrm{TiO}_{2}$, $\mathrm{MgO}$ and $\mathrm{CaO}$; and higher content of $\mathrm{P}_{2} \mathrm{O}_{5}$ when compared to the sample of Sardinha. The IP-135 (Ipanema) sample showed results, which were similar to the values found for the S-107 (Sardinha) sample. Finally, the sample of Bahia presented the highest values of $\mathrm{Al}_{2} \mathrm{O}_{3}$ and $\mathrm{MnO}$, while the sample of Sardinha presented the lowest values of $\mathrm{FeO}$ and the highest values of $\mathrm{MgO}, \mathrm{SiO}_{2}, \mathrm{~K}_{2} \mathrm{O}$ and $\mathrm{CaO}$.

The average EDX microanalyses results of the wüstite phase in the slag inclusions are shown in Table 4 for basic comparison. The wüstite phase presented higher $\mathrm{FeO}$ contents, usually above $90 \%$. The relative values of the standard deviations were higher than the ones found for matrix of the microstructure of the inclusions (see Table 3), probably due to the dilution of the non-ferrous oxides. The samples of Ipanema and Sardinha featured, however, the highest values of $\mathrm{V}_{2} \mathrm{O}_{5}$ content, while the sample of Missões featured the lowest content of $\mathrm{CaO}$ and the highest contents of $\mathrm{P}_{2} \mathrm{O}_{5}$ and $\mathrm{SiO}_{2}$. The sample of Bahia featured the highest values of $\mathrm{MnO}$ and $\mathrm{Al}_{2} \mathrm{O}_{3}$, while the samples of Bahia and Missões presented the highest $\mathrm{Al}_{2} \mathrm{O}_{3}$ contents. Finally, the sample of Sardinha presented the highest values of $\mathrm{V}_{2} \mathrm{O}_{5}, \mathrm{TiO}_{2}$ and $\mathrm{MgO}$.

The bivariate graph of $\mathrm{TiO}_{2}$ versus $\mathrm{V}_{2} \mathrm{O}_{5}$ in the wüstite phase is shown in Figure 3, indicating different clusters for the samples of Bahia and Missões. The graph also indicated 


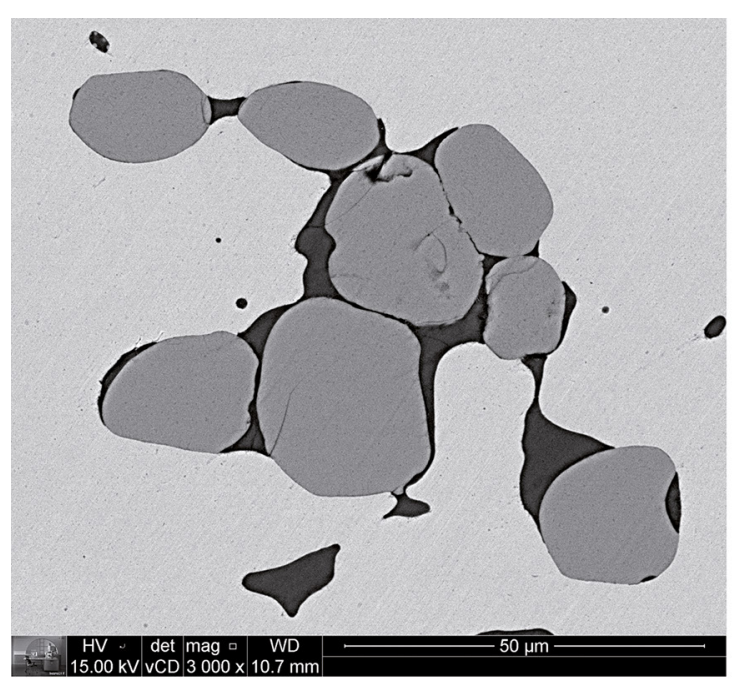

a) Ipanema

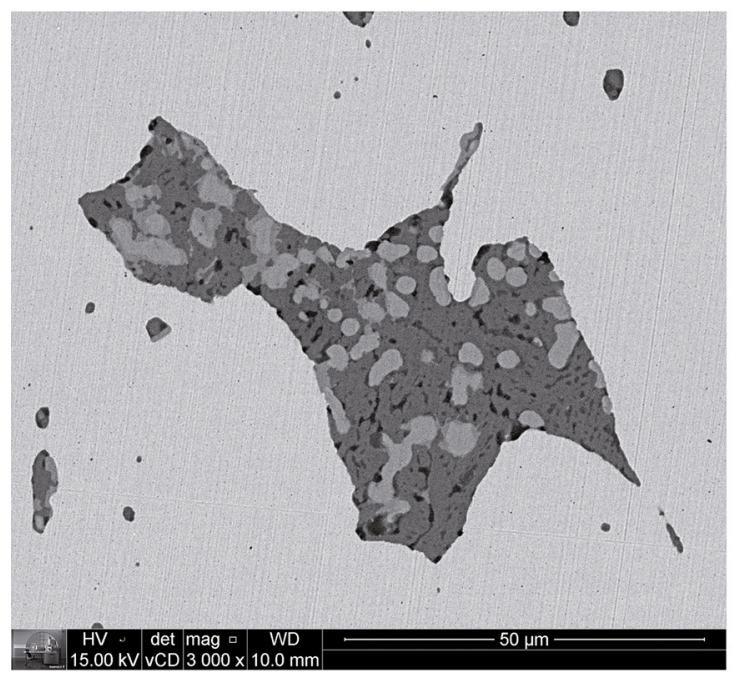

c) Missões

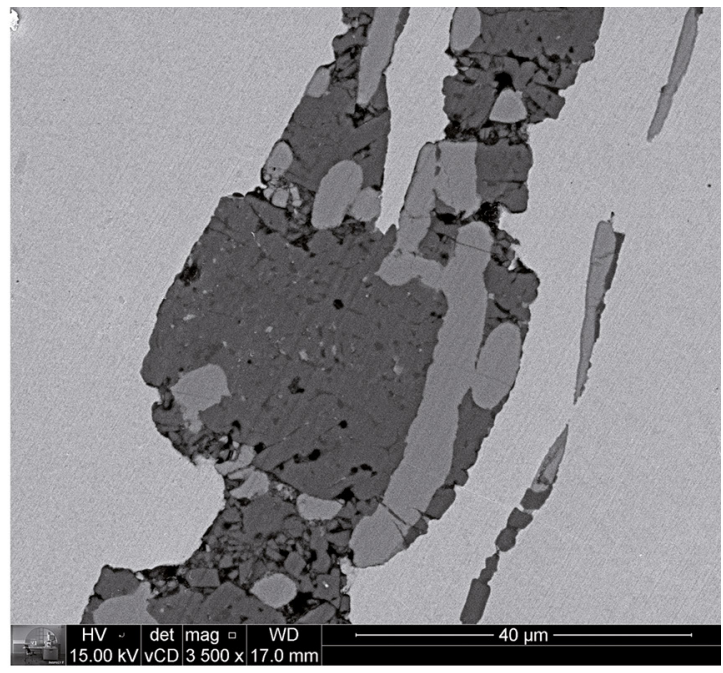

b) Bahia

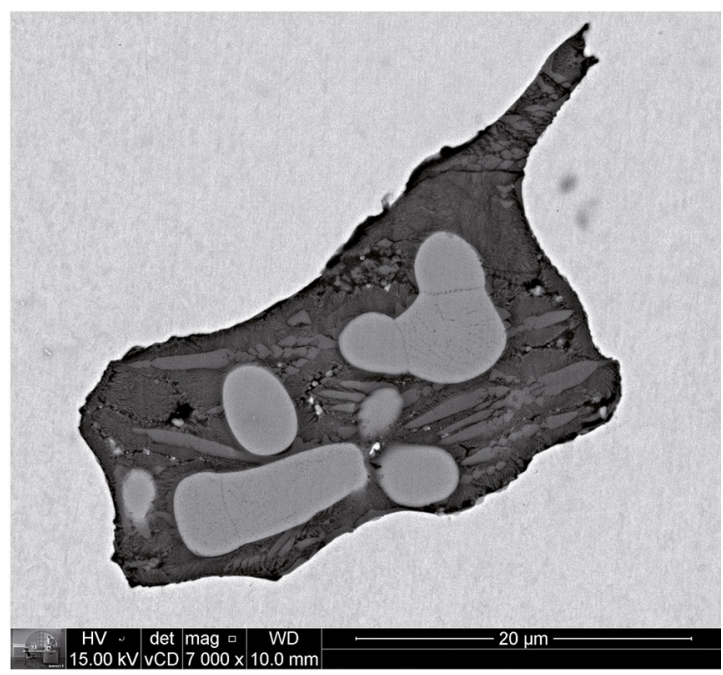

d) Sardinha

Figure 1: Typical microstructure of slag inclusions, featuring the presence of dendrites of wüstite, BEI, SEM: (a) Ipanema (Ip-135 sample); (b) Bahia (sample B-45); (c) Missions (M-123 sample); (d) Sardinha (S-107 sample).

Table 2: Average EDX microanalysis results of the "entire" multiphase slag inclusions.

\begin{tabular}{lcccccccccc}
\hline Sample & $\mathrm{MgO}$ & $\mathrm{SiO}_{2}$ & $\mathrm{P}_{2} \mathrm{O}_{5}$ & $\mathrm{~K}_{2} \mathrm{O}$ & $\mathrm{CaO}$ & $\mathrm{TiO}_{2}$ & $\mathrm{~V}_{2} \mathrm{O}_{5}$ & $\mathrm{MnO}$ & $\mathrm{Al}_{2} \mathrm{O}_{3}$ & $\mathrm{FeO}$ \\
\hline Ip-130 & $0.4 \pm 0.5$ & $6 \pm 6$ & $9 \pm 9$ & $0.4 \pm 0.4$ & $5 \pm 5$ & $0.4 \pm 0.3$ & $1.2 \pm 0.6$ & $0.6 \pm 0.4$ & $0.1 \pm 0.1$ & $78 \pm 17$ \\
$\mathrm{Ip}-131$ & $0.5 \pm 0.3$ & $10 \pm 5$ & $16 \pm 7$ & $0.5 \pm 0.5$ & $5 \pm 5$ & $0.5 \pm 0.5$ & $2 \pm 2$ & $0.8 \pm 0.4$ & $0.1 \pm 0.1$ & $64 \pm 12$ \\
$\mathrm{Ip}-133$ & $0.5 \pm 0.3$ & $8 \pm 6$ & $10 \pm 8$ & $0.4 \pm 0.3$ & $6 \pm 4$ & $0.5 \pm 0.5$ & $2 \pm 2$ & $0.6 \pm 0.2$ & $0.1 \pm 0.1$ & $73 \pm 16$ \\
$\mathrm{Ip}-134$ & $0.3 \pm 0.3$ & $5 \pm 4$ & $15 \pm 9$ & $0.2 \pm 0.2$ & $2 \pm 2$ & $0.3 \pm 0.3$ & $0.9 \pm 0.7$ & $0.5 \pm 0.3$ & $0.1 \pm 0.1$ & $77 \pm 9$ \\
$\mathrm{Ip}-135$ & $0.6 \pm 0.3$ & $12 \pm 12$ & $5 \pm 5$ & $0.6 \pm 0.5$ & $12 \pm 12$ & $0.6 \pm 0.3$ & $0.9 \pm 0.6$ & $0.5 \pm 0.3$ & $0.2 \pm 0.2$ & $71 \pm 27$ \\
$\mathrm{~B}-145$ & $0.1 \pm 0.1$ & $10 \pm 4$ & $8 \pm 6$ & $0.1 \pm 0.1$ & $0.2 \pm 0.2$ & $0.6 \pm 0.3$ & $0.3 \pm 0.2$ & $2 \pm 1$ & $1.6 \pm 0.5$ & $77 \pm 9$ \\
$\mathrm{M}-123$ & $0.6 \pm 0.5$ & $19 \pm 16$ & $10 \pm 6$ & $1 \pm 1$ & $4 \pm 3$ & $0.1 \pm 0.3$ & $0.2 \pm 0.2$ & $0.6 \pm 0.4$ & $1.5 \pm 1.3$ & $63 \pm 18$ \\
$\mathrm{~S}-107$ & $1.1 \pm 0.3$ & $15 \pm 6$ & $5 \pm 4$ & $2 \pm 1$ & $9 \pm 4$ & $0.9 \pm 0.5$ & $2 \pm 1$ & $1.3 \pm 0.3$ & $0.6 \pm 0.3$ & $64 \pm 12$ \\
\hline
\end{tabular}

a significant intersection for the results of Sardinha and Ipanema, which did not allow the separation of these results into two different clusters. Figure 3 suggests, however, that the inclusions of the sample of Sardinha tend to have higher contents of $\mathrm{V}_{2} \mathrm{O}_{5}$ and $\mathrm{TiO}_{2}$ in the wüstite phase than the samples of Ipanema. 


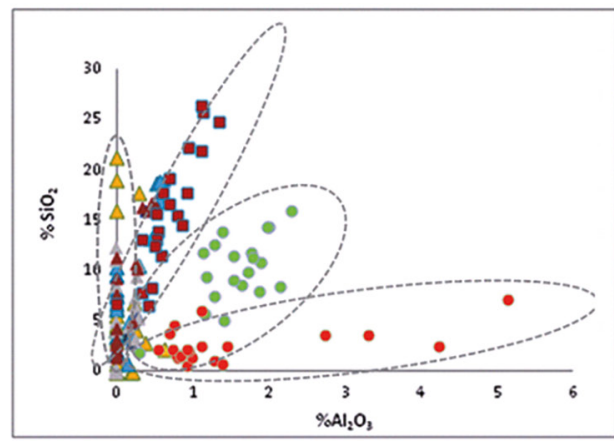

a)

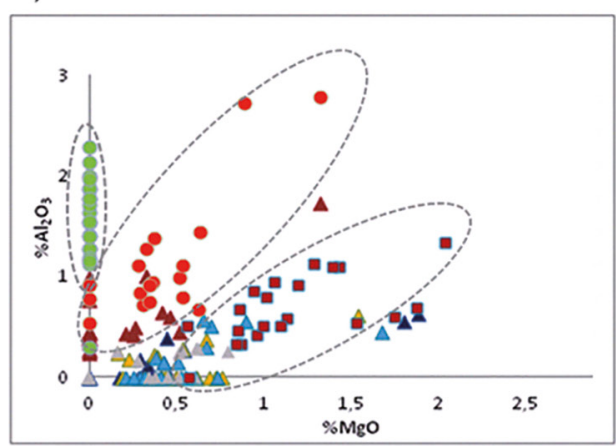

c)

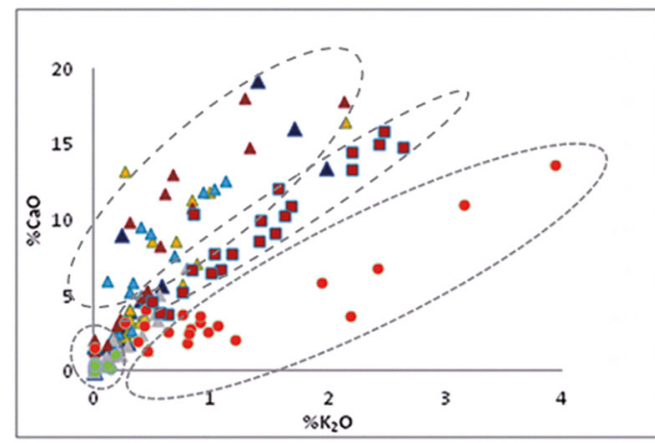

b)

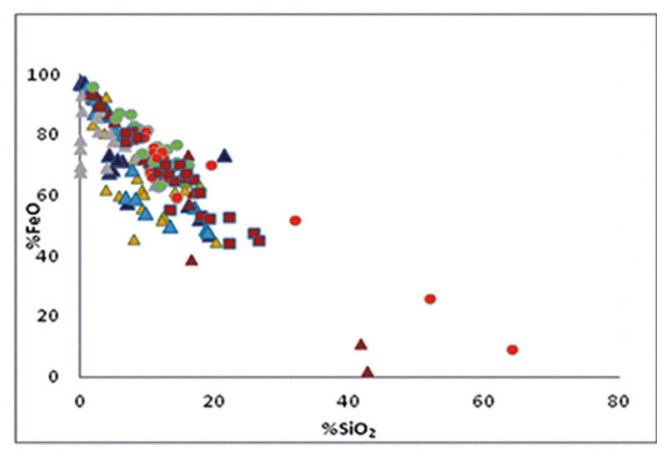

d)
A Ip-130

$\Delta \mid p-131$

$\Delta 1 \mathrm{p}-133$

Ip-134

$\Delta$ Ip-135

8-145

IN-123

S-107

Figure 2: Typical bivariate graphs showing the amount of oxides in the "entire" multiphase slag inclusions: (a) $\% \mathrm{SiO}_{2}$ versus $\% \mathrm{Al}_{2} \mathrm{O}_{3}$; (b) $\% \mathrm{CaO}$ versus $\% \mathrm{~K}_{2} \mathrm{O}$; (c) $\% \mathrm{Al}_{2} \mathrm{O}_{3}$ versus $\% \mathrm{MgO}$; and d) $\% \mathrm{FeO}$ versus $\% \mathrm{SiO}_{2}$.

Table 3: Average EDX microanalysis results of the matrix of the slag inclusions

\begin{tabular}{lcccccccccc}
\hline Sample & $\mathrm{MgO}$ & $\mathrm{SiO}_{2}$ & $\mathrm{P}_{2} \mathrm{O}_{5}$ & $\mathrm{~K}_{2} \mathrm{O}$ & $\mathrm{CaO}$ & $\mathrm{TiO}_{2}$ & $\mathrm{~V}_{2} \mathrm{O}_{5}$ & $\mathrm{MnO}$ & $\mathrm{Al}_{2} \mathrm{O}_{3}$ & $\mathrm{FeO}$ \\
\hline Ip-130 & $0.6 \pm 0.2$ & $10 \pm 7$ & $22 \pm 9$ & $0.8 \pm 0.6$ & $9 \pm 5$ & $0.1 \pm 0.1$ & $0.1 \pm 0.1$ & $0.7 \pm 0.2$ & $0.2 \pm 0.2$ & $57 \pm 7$ \\
$\mathrm{Ip}-131$ & $1.0 \pm 0.4$ & $18 \pm 3$ & $17 \pm 4$ & $0.9 \pm 0.6$ & $9 \pm 6$ & $0.1 \pm 0.1$ & $0.1 \pm 0.1$ & $1.0 \pm 0.1$ & $0.2 \pm 0.2$ & $53 \pm 8$ \\
$\mathrm{Ip}-133$ & $0.8 \pm 0.2$ & $17 \pm 5$ & $19 \pm 5$ & $0.9 \pm 0.7$ & $10 \pm 6$ & $0.1 \pm 0.1$ & $0.1 \pm 0.1$ & $0.8 \pm 0.2$ & $0.3 \pm 0.3$ & $52 \pm 8$ \\
$\mathrm{Ip}-134$ & $0.9 \pm 0.3$ & $16 \pm 4$ & $17 \pm 4$ & $0.8 \pm 0.7$ & $7 \pm 4$ & $0.1 \pm 0.1$ & $0.1 \pm 0.1$ & $0.9 \pm 0.2$ & $0.2 \pm 0.2$ & $58 \pm 6$ \\
$\mathrm{Ip}-135$ & $0.8 \pm 0.3$ & $24 \pm 7$ & $7 \pm 5$ & $1.1 \pm 0.6$ & $14 \pm 8$ & $0.4 \pm 0.3$ & $0.2 \pm 0.2$ & $0.8 \pm 0.4$ & $0.6 \pm 0.3$ & $51 \pm 12$ \\
$\mathrm{~B}-145$ & $0.1 \pm 0.1$ & $18 \pm 4$ & $13 \pm 6$ & $0.1 \pm 0.1$ & $0.4 \pm 0.3$ & $0.2 \pm 0.2$ & $0.1 \pm 0.1$ & $3.4 \pm 0.7$ & $2 \pm 1$ & $63 \pm 2$ \\
$\mathrm{M}-123$ & $0.4 \pm 0.0$ & $17 \pm 2$ & $13 \pm 3$ & $0.8 \pm 0.1$ & $4.2 \pm 0.3$ & $0.1 \pm 0.1$ & $0.1 \pm 0.1$ & $0.5 \pm 0.1$ & $0.7 \pm 0.3$ & $64 \pm 5$ \\
$\mathrm{~S}-107$ & $1.4 \pm 0.3$ & $25 \pm 5$ & $9 \pm 4$ & $2.3 \pm 0.9$ & $15 \pm 5$ & $0.4 \pm 0.2$ & $0.2 \pm 0.2$ & $1.5 \pm 0.3$ & $0.9 \pm 0.4$ & $45 \pm 8$
\end{tabular}

Table 4: Average EDX microanalysis results of the wüstite phase of the slag inclusions

\begin{tabular}{lccccccccc}
\hline Sample & $\mathrm{MgO}$ & $\mathrm{SiO}_{2}$ & $\mathrm{P}_{2} \mathrm{O}_{5}$ & $\mathrm{CaO}$ & $\mathrm{TiO}_{2}$ & $\mathrm{~V}_{2} \mathrm{O}_{5}$ & $\mathrm{MnO}$ & $\mathrm{Al}_{2} \mathrm{O}_{3}$ & $\mathrm{FeO}$ \\
\hline Ip-130 & $0.2 \pm 0.2$ & $0.4 \pm 0.2$ & $0.1 \pm 0.1$ & $0.1 \pm 0.1$ & $0.5 \pm 0.2$ & $1.7 \pm 0.6$ & $0.3 \pm 0.2$ & $0.1 \pm 0.1$ & $97 \pm 1$ \\
Ip-131 & $0.1 \pm 0.1$ & $0.6 \pm 0.3$ & $0.2 \pm 0.2$ & $0.2 \pm 0.2$ & $1.0 \pm 0.3$ & $3.0 \pm 0.6$ & $0.4 \pm 0.2$ & $0.1 \pm 0.1$ & $95 \pm 1$ \\
Ip-133 & $0.2 \pm 0.2$ & $0.3 \pm 0.1$ & $0.1 \pm 0.1$ & $0.1 \pm 0.1$ & $0.3 \pm 0.2$ & $1.5 \pm 0.6$ & $0.1 \pm 0.2$ & $0.1 \pm 0.1$ & $98 \pm 1$ \\
Ip-134 & $0.1 \pm 0.1$ & $0.5 \pm 0.5$ & $0.8 \pm 0.8$ & $0.1 \pm 0.1$ & $0.5 \pm 0.4$ & $2.0 \pm 0.7$ & $0.2 \pm 0.2$ & $0.1 \pm 0.1$ & $96 \pm 2$ \\
Ip-135 & $0.2 \pm 0.1$ & $0.3 \pm 0.1$ & $0.1 \pm 0.1$ & $0.1 \pm 0.1$ & $0.6 \pm 0.3$ & $1.6 \pm 0.9$ & $0.4 \pm 0.1$ & $0.1 \pm 0.1$ & $97 \pm 2$ \\
B-145 & $0.1 \pm 0.1$ & $0.8 \pm 0.3$ & $0.1 \pm 0.1$ & $0.1 \pm 0.1$ & $0.9 \pm 0.1$ & $0.5 \pm 0.2$ & $0.9 \pm 0.4$ & $0.5 \pm 0.1$ & $96 \pm 1$ \\
M-123 & $0.1 \pm 0.1$ & $3 \pm 2$ & $4 \pm 3$ & $0.3 \pm 0.3$ & $0.1 \pm 0.1$ & $0.3 \pm 0.2$ & $0.1 \pm 0.1$ & $0.6 \pm 0.3$ & $92 \pm 5$ \\
S-107 & $0.4 \pm 0.2$ & $0.9 \pm 0.4$ & $0.1 \pm 0.1$ & $0.3 \pm 0.2$ & $1.2 \pm 0.3$ & $3.2 \pm 0.9$ & $0.7 \pm 0.1$ & $0.1 \pm 0.1$ & $93 \pm 1$ \\
\hline
\end{tabular}




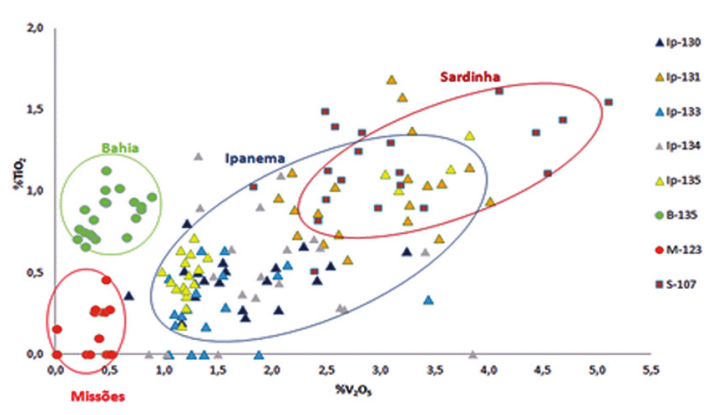

Figure 3: Bivariate graph showing the amount of oxides $\left(\% \mathrm{TiO}_{2}\right.$ versus $\% \mathrm{~V}_{2} \mathrm{O}_{5}$ ) in the wüstite phase of the slag inclusions.

After a critical examination of all EDX results, the authors applied the multivariate method and hierarchical cluster analysis ${ }^{10,20}$ for the 480 microanalysis results (the entire multiphase inclusions, the matrix of the inclusions and the wüstite phase), using different sets of critical variables for each group of results (see Table 5). The resulting dendrograms - featuring a dotted line which separated the results into fours clusters - are shown in Figures 4 to 6 .

\section{Discussion}

\subsection{Inclusion microanalysis versus production processing of iron parts}

All investigated samples have a large volume fraction of slag inclusions (see table 1), indicating that none of them were produced in the XX century, which could indicate a possible contamination during the sampling of the sites. The sample of Bahia showed a large volumetric fraction of slag inclusions $(\sim 6 \%)$, suggesting that the Scottish iron plates material used to build the railway bridge in Bahia were produced by puddling. By contrast, the samples of Ipanema showed a much lower volumetric fraction of slag inclusions $(\sim 1 \%)$, which was related to the exceptional expertise on the control of the Styrian process, which was introduced in the Royal Iron Factory of São João de Ipanema by a group of Austrian ironworkers ${ }^{17}$.
The microstructure the "matrix" of the slag inclusions was typically more complex than the description used in the present work (see Figures 1-a to 1-d), being usually composed by the eventual presence of fayalite $\left(2 \mathrm{FeO} . \mathrm{SiO}_{2}\right)$ phase in a glassy phase ${ }^{15}$. All samples showed the presence of dendritic wustite $(\mathrm{FeO})$ phase inside the slag inclusions, which is compatible with the high FeO content in the inclusions (Table 2 ). These values were similar to the values observed in the archaeometallurgical literature ${ }^{7-16}$. High $\mathrm{FeO}$ content in the slag is usually associated with the oxidizing conditions in the refining step of the indirect process, when the high carbon content of the pig iron must be oxidized. It is somehow surprising that high $\mathrm{FeO}$ contents were observed for the samples of Sardinha and Missões, which were produced in more reducing conditions (direct process).

The relatively high $\mathrm{SiO}_{2}$ content observed in the slag inclusions, especially in the "matrix" (see Table 3), is rather common, as the addition of $\mathrm{SiO}_{2}$ is known to decrease the melting point of the slag and increase its fluidity during processing ${ }^{15}$. Phosphorous oxide was also present in all samples, especially in the matrix of the inclusions (Table 3). Dillmann et al. ${ }^{7}$ indicated that the phosphorous content of the artifacts produced by the indirect process tended to be higher than the ones produced by the direct process. Table 3 indicated that the sample of Sardinha (produced by direct process) featured $\mathrm{P}_{2} \mathrm{O}_{5}$ content below $10 \%$, while most of the samples of Ipanema (likely produced by indirect process) presented $\mathrm{P}_{2} \mathrm{O}_{5}$ content higher than $17 \%$ (except for Ip-135 sample, which presented $\mathrm{P}_{2} \mathrm{O}_{5}$ content around 7\%). The sample of Bahia (produced by indirect process) showed a $\mathrm{P}_{2} \mathrm{O}_{5}$ content of $13 \%$, which is the same content observed for the samples of Missões (likely produced by direct process). These results suggested that the $\mathrm{P}_{2} \mathrm{O}_{5}$ content of the matrix of the slag inclusions cannot be used as a single variable to identify the type of processing of the ferrous artifacts.

The presence of $\mathrm{TiO}_{2}$ in the slag inclusions of the samples of Ipanema and Sardinha was predominantly concentrated in the wüstite phase (see Tables 2 to 4). This observation was consistent with the amount of $\mathrm{Ti}(\sim 3 \%$ Ti) found in the local magnetitic iron ore of the Araçoiaba Hill $^{21}$. Iron ores with high Ti content are usually attributed

Table 5: Characteristic components present in the slag inclusions, including their main microconstituents (matrix and wüstite), for each group of samples

\begin{tabular}{|c|c|c|c|}
\hline Group of samples & Entire slag inclusions & Matrix & Wüstite phase \\
\hline Ipanema & $\mathrm{P}_{2} \mathrm{O}_{5}, \mathrm{CaO}$ and $\mathrm{V}_{2} \mathrm{O}_{5}$ & $\mathrm{P}_{2} \mathrm{O}_{5}$ & $\mathrm{TiO}_{2}$ and $\mathrm{V}_{2} \mathrm{O}_{5}$ \\
\hline Bahia & $\mathrm{MnO}$ and $\mathrm{Al}_{2} \mathrm{O}_{3}$ & $\mathrm{MnO}$ and $\mathrm{Al}_{2} \mathrm{O}_{3}$ & $\mathrm{Al}_{2} \mathrm{O}_{3}$ and $\mathrm{MnO}$ \\
\hline Missões & $\mathrm{SiO}_{2}$ and $\mathrm{Al}_{2} \mathrm{O}_{3}$ & $\mathrm{Al}_{2} \mathrm{O}_{3}$ & $\mathrm{SiO}_{2}, \mathrm{P}_{2} \mathrm{O}_{5}$ and $\mathrm{Al}_{2} \mathrm{O}_{3}$ \\
\hline Sardinha & $\mathrm{MgO}, \mathrm{K}_{2} \mathrm{O}, \mathrm{TiO}_{2}$ and $\mathrm{V}_{2} \mathrm{O}_{5}$ & $\begin{array}{c}\mathrm{MgO}, \mathrm{SiO}_{2}, \mathrm{~K}_{2} \mathrm{O}, \mathrm{TiO}_{2} \text { and } \\
\mathrm{Al}_{2} \mathrm{O}_{3}\end{array}$ & $\mathrm{MgO}, \mathrm{TiO}_{2}$ and $\mathrm{V}_{2} \mathrm{O}_{5}$ \\
\hline $\begin{array}{l}\text { Critical set of oxides used for the } \\
\text { cluster analysis }\end{array}$ & $\begin{array}{c}\mathrm{P}_{2} \mathrm{O}_{5}, \mathrm{MgO}, \mathrm{SiO}_{2}, \mathrm{~K}_{2} \mathrm{O}, \mathrm{CaO} \\
\mathrm{TiO}_{2} \text { and } \mathrm{Al}_{2} \mathrm{O}_{3}\end{array}$ & $\begin{array}{c}\mathrm{CaO}, \mathrm{P}_{2} \mathrm{O}_{5}, \mathrm{~K}_{2} \mathrm{O}, \mathrm{TiO}_{2} \text { and } \\
\mathrm{Al}_{2} \mathrm{O}_{3}\end{array}$ & $\begin{array}{c}\mathrm{MgO}, \mathrm{Al}_{2} \mathrm{O}_{3}, \mathrm{~V}_{2} \mathrm{O}_{5}, \mathrm{MnO} \text { and } \\
\mathrm{TiO}_{2}\end{array}$ \\
\hline Detected outliers & $\mathrm{V}_{2} \mathrm{O}_{5}, \mathrm{Cr}_{2} \mathrm{O}_{3}$ and $\mathrm{MnO}$ & $\begin{array}{c}\mathrm{MgO}, \mathrm{SiO}_{2}, \mathrm{~V}_{2} \mathrm{O}_{5}, \mathrm{Cr}_{2} \mathrm{O}_{3} \text { and } \\
\mathrm{MnO}\end{array}$ & $\begin{array}{c}\mathrm{SiO}_{2}, \mathrm{P}_{2} \mathrm{O}_{5}, \mathrm{~K}_{2} \mathrm{O}, \mathrm{CaO} \text { and } \\
\mathrm{Cr}_{2} \mathrm{O}_{3}\end{array}$ \\
\hline
\end{tabular}




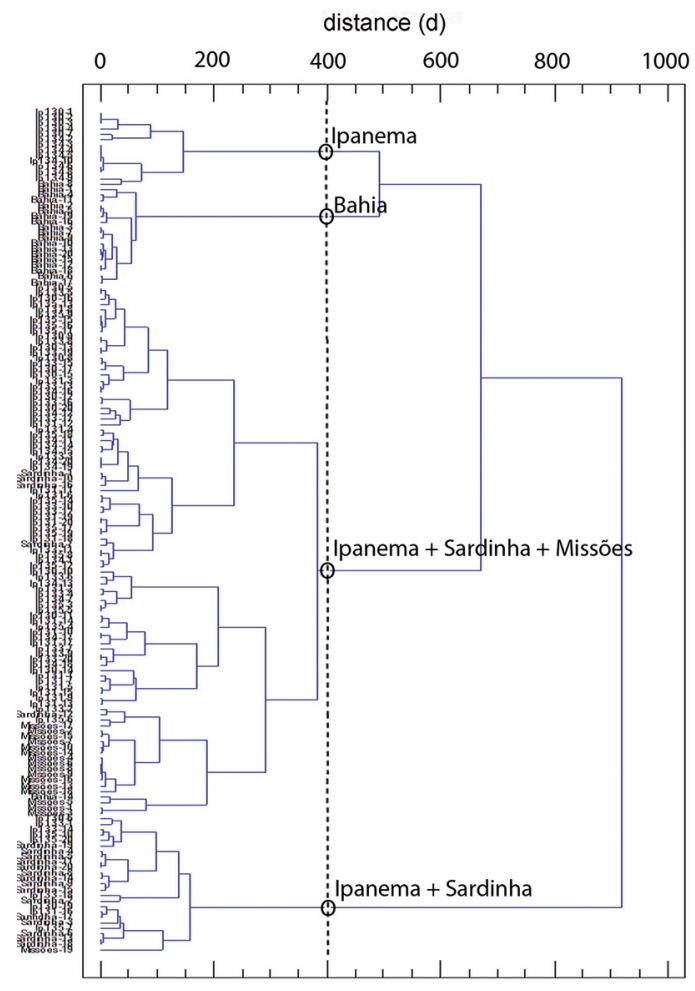

Figure 4: Dendrogram using the treated EDX results of the entire multiphase slag inclusions.

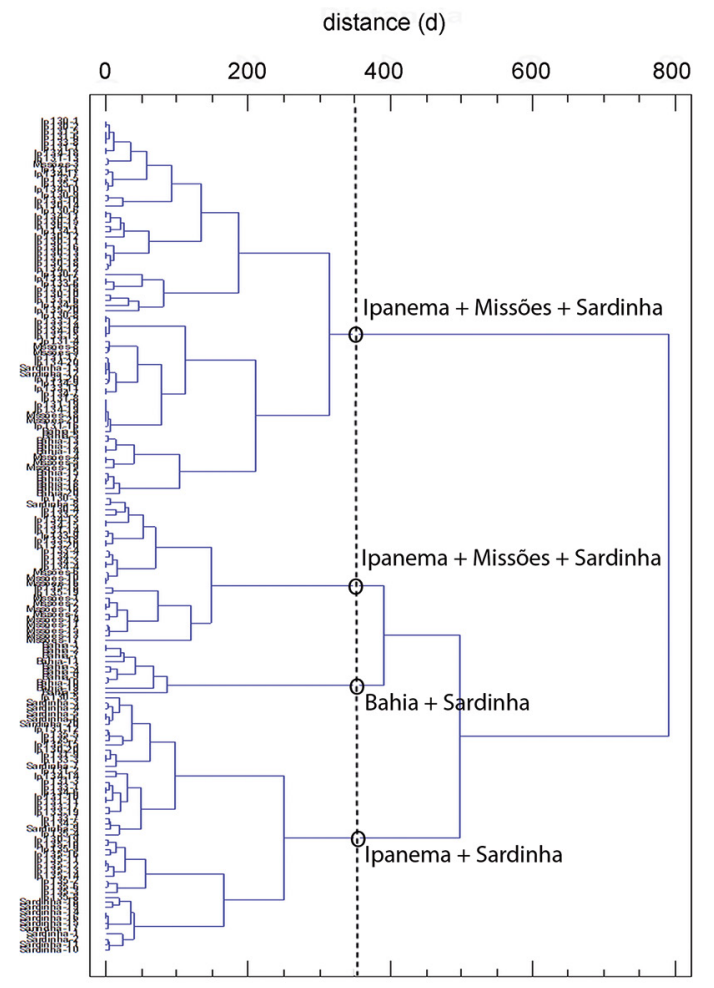

Figure 5: Dendrogram using the treated EDX results of the "matrix" of the slag inclusions.

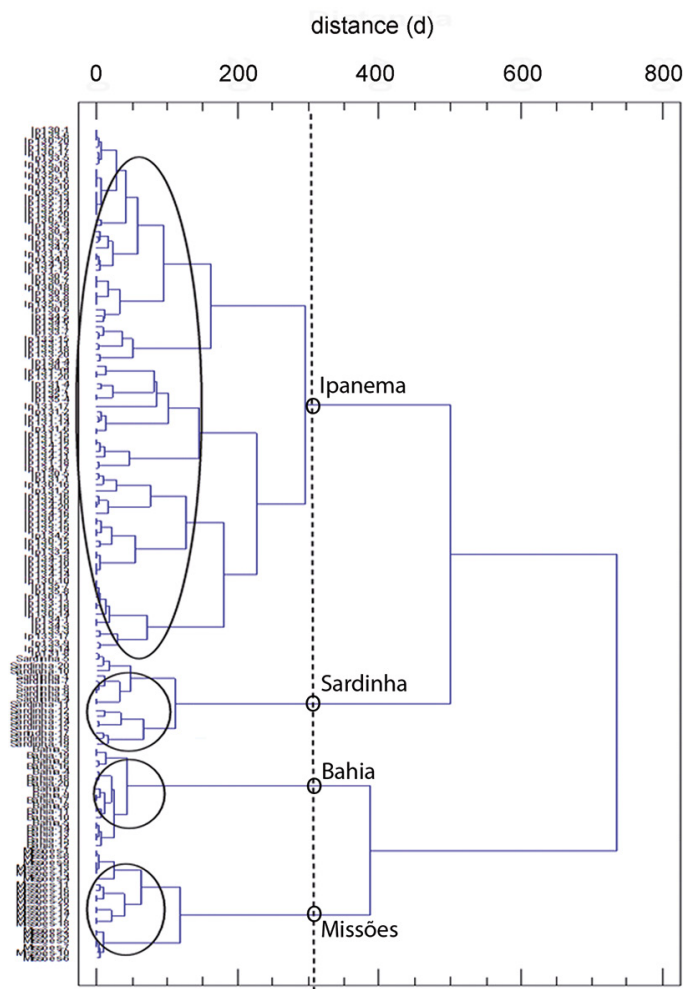

Figure 6: Dendrogram using the treated EDX results of the wüstite phase of the slag inclusions.

to magmatic origins ${ }^{22}$, which is the case of the carbonatite of the Araçoiaba hill. By contrast, $\mathrm{TiO}_{2}$ was not observed in the wüstite phase of the sample of Missões, which is in agreement with previous work ${ }^{23}$. Hüttner and co-workers ${ }^{23}$ investigated the slag inclusions of ferrous artifacts from the site of Missões and observed the presence of $\mathrm{Ti}$ in the wüstite phase only for one sample from a total of four. It is not absolutely certain, however, whether the ferrous objects collected in the archaelogical site of Missões were produced from local iron ore or imported from Europe ${ }^{5}$.

Vanadium was found in the wüstite phase of all samples, although the samples of Ipanema and Sardinha presented the highest values of $\mathrm{V}_{2} \mathrm{O}_{5}$ (see Table 4). Figure 3 indicated that the inclusions of the sample of Sardinha tend to present higher contents of $\mathrm{V}_{2} \mathrm{O}_{5}$ and $\mathrm{TiO}_{2}$ in the wüstite phase than the samples of Ipanema. Most of the literature, however, did not mention the presence of V in the slag inclusions ${ }^{7-11,13}$, only Buchwald ${ }^{12}$ observed its presence. The samples of Ipanema and Sardinha presented $\mathrm{V}_{2} \mathrm{O}_{5}$ contents higher than $\mathrm{TiO}_{2}$ (see Table 4 and Figure 3), although the chemical analysis of the iron ore of the Araçoiaba hill showed the opposite proportion between $\mathrm{V}$ and $\mathrm{Ti}(3 \% \mathrm{Ti}$ and $0.45 \% \mathrm{~V})$. Additionally, there is a geological evidence that magmatic iron ores usually contain proportionally higher content of Ti than $\mathrm{V}^{22}$. This question will be answered by future microstructural and chemical analyses of samples of the pig iron, the blast furnace slag and the refining slag of 
Ipanema available in the Geological Collection of the National Museum in Rio de Janeiro. Finally, the amounts of $\mathrm{TiO}_{2}, \mathrm{~V}_{2} \mathrm{O}_{5}$ and $\mathrm{MnO}$ in the wüstite phase of the sample of Bahia sample suggests that the iron ore of the Mossend Iron and Steel Works contained significant amounts of Ti, Mn and V.

\subsection{Hierarchical cluster analysis}

Multivariate method and hierarchical cluster analysis were applied using a critical set of variables and outliers for each family of microanalysis results (see Table 5 and Figures 4 to 6). The dendrogram using the treated EDX results of the entire multiphase slag inclusions and a set of critical variables defined by $\mathrm{P}_{2} \mathrm{O}_{5}, \mathrm{MgO}, \mathrm{SiO}_{2}, \mathrm{~K}_{2} \mathrm{O}$, $\mathrm{CaO}, \mathrm{TiO}_{2}$ and $\mathrm{Al}_{2} \mathrm{O}_{3}$ (see Figure 4) showed that the four clusters (for a Euclidean distance of approximately 400) were not correctly related to their sites. The third cluster, for instance, contained slag inclusions from three different sites. The dendrogram using the treated EDX results of the matrix of the slag inclusions and a set of critical variables defined by $\mathrm{CaO}, \mathrm{P}_{2} \mathrm{O}_{5}, \mathrm{~K}_{2} \mathrm{O}, \mathrm{TiO}_{2}$ and $\mathrm{Al}_{2} \mathrm{O}_{3}$ (see Figure 5 ) showed the same behavior. Only the dendrogram using the results of the wüstite phase (see Figure 6) and a set of critical oxides defined by $\mathrm{MgO}, \mathrm{Al}_{2} \mathrm{O}_{3}, \mathrm{~V}_{2} \mathrm{O}_{5}, \mathrm{MnO}$ and $\mathrm{TiO}_{2}$ allowed the accurate separation and precise grouping of the samples of each one of the investigated sites (Sardinha, Ipanema, Bahia and Missões) for a Euclidean distance of approximately 300 .

The choice of the critical set of oxides and the detection of the outliers were important stages of the hierarchical cluster analysis, which depended on the careful examination and data treatment of all 480 EDX results ${ }^{20}$. In the present investigation, four clusters could be identified in all dendrograms, but only the dendrogram for the wüstite phase (see Figure 6) allowed the separation of the samples into four clusters effectively representing the four production sites of Missões, Bahia, Ipanema and Sardinha.

The most important features in the present work compared to previous investigation ${ }^{11}$ were the use of the microanalysis results of the wüstite phase and the inclusion of the $\mathrm{MnO}$ and $\mathrm{V}_{2} \mathrm{O}_{5}$ contents in the critical set of variables (see Table 5). Charlton et al. ${ }^{11}$, for instance, used during the cluster analysis a set of critical variables with six oxides $\left(\mathrm{MgO}, \mathrm{Al}_{2} \mathrm{O}_{3}, \mathrm{SiO}_{2}, \mathrm{CaO}\right.$ and $\left.\mathrm{TiO}_{2}\right)$ and their microanalyses were representative of the whole volume of the slag inclusions. The new methodology used in the present investigation should be statistically verified with regard to the number of samples and production sites. Hierarchical cluster analysis was a reliable tool to separate the groups of samples, but the number of the distinct groups of samples in the present investigation was well known. When this number is not known, the choice of the Euclidian distance to define the number of clusters can be a rather subjective matter ${ }^{11,20}$.

\subsection{A new approach to the history of the Royal Iron Factory of São João de Ipanema}

The historian Paulo Araújo ${ }^{24}$ stated that there are evidences of the use of good process practices concerning the ironmaking at the Royal Iron Factory of São João de Ipanema, contradicting a significant body of Brazilian literature ${ }^{25-27}$. His statement was based on at least three pieces of evidences: firstly the paper ${ }^{17}$ written by L. Dupré (Ipanema engineer) and published in 1885 at the Journal of the School of Mines of Ouro Preto, which described the technical operation of the Ipanema factory in great detail. Additionally, this paper cited relevant international references to the subject, indicating the familiarity of the engineers of Ipanema with the technological aspects of the ironmaking process, including the Styrian process of decarburizing the pig iron $(\sim 4 \% \mathrm{C})$. Karsten's and Tunner's books ${ }^{28-29}$, which were mentioned in this paper, were vital bibliography in the field of ironmaking for most of the XIX century. Finally, the Ipanema factory had a well established library on ironmaking since 1810 mostly based on Swedish and German literature ${ }^{28-30}$.

"The process employed at Ipanema for the transformation of pig iron in wrought iron is the same used in Leoben, High Styria, here imported by the refining workmen hired in that part of Austria. This process differs significantly in some points from that described by Karsten in his treaty on metallurgy, under the designation of Styrian process. Today's forge at Ipanema is similar to one working in Reichenau, about which P. Tunnner writes in his book."

The low volume fraction of slag inclusions of Ipanema's bars shown in the present paper (see Table 1) can be another piece of evidence, confirming the idea of Paulo Araújo about the use of good processing practices in the factory of Ipanema. The superior quality of its ferrous products, specially the ductility, had been attested by a report published in 1883 by a railroad company ${ }^{31}$. The fact that no other blast furnaces were built in Brazil up to 1888 should be an important topic for economic historians. Market size, logistics, competition from imports and lack of capital could explain the situation in the beginning of the XIX century, but not after the coffee boom wealth allowed the railroad expansion in the State of São Paulo.

Archaeometallurgical investigations can greatly improve our understanding of the history and our culture by improving our awareness of our technological development ${ }^{32}$. The technological aspects of the processing of metallic products can be partially deciphered by the microstructural characterization of these artifacts associated with the collection and interpretation of historical documentation ${ }^{32-41}$. Our ability to accurately reply to all the cultural, commercial and technological questions is, indeed, very limited (either by sampling or lack of documentation) but there are few investigators eager to apply microstructural characterization 
techniques to, somehow, elucidate the history of technology, the dating of objects, the spread of technologies and the nature and implications of the contact between different cultures ${ }^{32}$.

\section{Conclusions}

- $\quad$ EDX microanalyses of the entire multiphase inclusions and their microconstituents of ferrous artifacts - Royal Iron Factory of São João de Ipanema, D. Pedro II Bridge (Bahia, Brazil and produced in Scotland) and archaeological sites of São Miguel de Missões (Rio Grande do Sul, Brazil) and Afonso Sardinha (São Paulo, Brazil) - were carried out but these results, which were organized as bivariate graphs, were not capable to successfully separate the four groups of samples according to their provenance.

- The bivariate graph of $\mathrm{TiO}_{2}$ versus $\mathrm{V}_{2} \mathrm{O}_{5}$ in the wüstite phase effectively distinguished two clusters for the samples of Bahia and Missões, but could not separate the results from Ipanema and Sardinha. The suggested, however, that the Sardinha's inclusions tend to feature higher contents of $\mathrm{V}_{2} \mathrm{O}_{5}$ and $\mathrm{TiO}_{2}$ than the inclusions of Ipanema's samples.

- Titanium and vanadium content in the wüstite crystals inside the slag inclusions are a promising reference for obtaining the chemical signature of wrought iron samples of Ipanema and Sardinha.

- The dendrogram with the microanalysis results of the wüstite phase (using as critical variables the contents of $\mathrm{MnO}, \mathrm{MgO}, \mathrm{Al}_{2} \mathrm{O}_{3}, \mathrm{~V}_{2} \mathrm{O}_{5}$ and $\mathrm{TiO}_{2}$ ) allowed the identification of four clusters, which successfully represented the samples of the four production sites (Ipanema, Sardinha, Missões and Bahia).

- $\quad$ The average volume fraction of slag inclusions observed in the samples of Ipanema $(\sim 1 \%)$ suggested the presence of fine technological expertise on the control of the indirect process of the Royal Iron Factory of São João de Ipanema.

\section{Acknowledgments}

F. J. G. Landgraf and C. R. F. Azevedo would like to thank the National Council for Scientific and Technological Development $(\mathrm{CNPq})$ for the research grant. The authors also would like to express their gratitude to the Historian P. E. M. Araújo (Institute of Geosciences, Unicamp, Brazil); to Prof. R. Ramos and Mr. R. A. Azevedo (Museu Nacional, Rio de Janeiro, Brazil); to Dr.-Ing. A. H. Feller; to Prof. B. Dedavid and Prof. E. Hüttner (both from the Pontifícia Universidade Católica, Rio Grande do Sul, Brazil); to MEng. M. F. Moreira and Dr. T. Yonamine (Institute for Technological Research); to Prof. Dr. A. C. Neiva, MEng. R. R. Maia, Mr. V. Santos and Prof. T. N. Bittencourt. (Polytechnic School, University of São Paulo); and to Mr. L. B. Regalado (Floresta Nacional de Ipanema, Instituto Chico Mendes de Conservação da Biodiversidade, Ministério do Meio Ambiente do Brazil). Finally, the authors dedicate this work to the memories of Prof. M. D. Andreatta, whose pioneer work on the Ipanema site allowed the collection and preservation of significant historical artifacts, and Mr. A. C. Azevedo.

\section{References}

1. Baer W. The development of the Brazilian steel industry. Nashville: Vanderbilt University Press; 1969. 202 p.

2. Santos NP. A fábrica de ferro São João de Ipanema: economia e politica nas últimas décadas do segundo reinado (18601889). [Master's Dissertation]. São Paulo: Faculdade de Filosofia, Letras e Ciência Humanas, Universidade de São Paulo; 2009. 180 p.

3. Landgraf FJG, Araújo PEM, Schroeder R. Ipanema e os alemães. In: Martius-Staden-Jahrbuch, 61. São Leopoldo: Oikos; São Paulo: Instituto Martius-Staden; 2016. In Press.

4. Zequini A. Arqueologia de uma fábrica de ferro: Morro de Araçoiaba, séculos XVI-XVIII. [PhD Thesis]. São Paulo: Museu de Arqueologia e Etnologia, Universidade de São Paulo; 2006. 223 p.

5. Zanettini PE, Camargo PFB. Arqueologia no Parque Fonte Missioneira: Programa de prospecções arqueológicas Parque Fonte Missioneira. São Miguel das Missões, Rio Grande do Sul. Relatório Final. São Paulo: Zanettini Arqueologia, Instituto de Patrimônio Histórico de Artístico; 2010. 142 p.

6. Marques AC, Borges AR, Bittencourt TN. Evaluation and modelling of wrought iron bridge in Bahia. In: Chen A, Frangopol DM, Ruan X, eds. Bridge Maintenance, Safety, Management and Life Extension. Boca Raton: CRC Press; 2014. p. 334-339.

7. Dillmann P, L'Héritier M. Slag inclusion analyses for studying ferrous alloys employed in French medieval buildings: supply of materials and diffusion of smelting processes. Journal of Archaeological Science. 2007;34(11):1810-1823.

8. Blakelock E, Martinón-Torres M, Veldhuijzen VH, Young T. Slag inclusions in iron objects and the quest for provenance: an experiment and a case study. Journal of Archaeological Science. 2009;36(8):1745-1757.

9. Crew P. The experimental production of Prehistoric bar iron. Historical Metallurgy. 1991;25:21-36.

10. Desaulty AM, Dillmann P, L'Heritier M, Mariet C, Gratuze B, Joron JL, et al. Does it come from the Pays de Bray? Examination of an origin hypothesis for the ferrous reinforcements used in French medieval churches using major and trace element analyses. Journal of Archaeological Science. 2009;36(10):2445-2462.

11. Charlton MF, Blakelock E, Martinón-Torres M, Young T. Investigating the production provenance of iron artifacts with multivariate methods. Journal of Archaeological Science. 2012;39(7):2280-2293. 
12. Buchwald VF, Wivel H. Slag Analysis as a Method for the Characterization and Provenancing of Ancient Iron Objects. Materials Characterization. 1998;40(2):73-96.

13. Disser A, Dillmann P, Bourgain C, L'Héritier M, Vega E, Bauvais $\mathrm{S}$, et al. Iron reinforcements in Beauvais and Metz Cathedrals: from bloomery or finery? The use of logistic regression for differentiating smelting processes. Journal of Archaeological Science. 2014;42:315-333.

14. Maia RR, Dias SM, Azevedo CRF, Landgraf FJG. Archaeometry of ferrous artefacts from Luso-Brazilian archaeological sites near Ipanema River, Brazil. REM, Revista Escola de Minas. 2015;68(2):187-193.

15. Maia RR. Análise de inclusões de escória em amostras arqueológicas da fábrica de ferro de Ipanema. [MEng. Dissertation]. São Paulo: Escola Politécnica, Universidade de São Paulo; 2014. 209 p.

16. Maia RR, Azevedo CRF, Landgraf FJG. Análise de inclusões de escória em amostras da fábrica de ferro de Ipanema. In: $67^{\circ}$ Congresso ABM Internacional; 2012 Jul 31 - Ago 3; Rio de Janeiro, RJ, Brazil.

17. Dupré L. Memória sobre a Fábrica de Ferro de São João do Ipanema. Annaes da Escola de Minas de Ouro Preto. 1885;4:37-67.

18. Carle CB. Metalurgia nas Missões - uma introdução. [Master's Thesis]. Porto Alegre: Pontifícia Universidade Católica do Rio Grande do Sul (PUCRS); 1993. 200 p.

19. Lewis J, Murdoch R. Excavations at Summerlee Ironworks, Coatbridge, North Lanarkshire. Proceedings of the Society of Antiquaries of Scotland. 2007;137:501-529.

20. Johnson RA, Wichern DW. Applied multivariate statistical analysis. Sixth edition. London: Pearson Education Inc; 2007. 767 p.

21. Guarino V, Azzone RG, Brotzu P, Gomes CB, Melluso L, Morbidelli L, et al. Magmatism and fenitization in the Cretaceous potassium-alkaline-carbonatitic complex of Ipanema, São Paulo State, Brazil. Mineralogy and Petrology. 2012;104(1):43-61.

22. Marsden RW. Iron ore exploration and geology. In: Kennedy BA, ed. Surface Mining. Englewood: Society for Mining, Metallurgy and Exploration; 1990.

23. Hüttner E, Hüttner EA, Oliveira GBV, Vivian DL, Dedavid BA. Caracterização metalográfica de uma cruz metálica da cidade de Camaquã (RS). Revista Liberato. 2015;16(26):177-191.

24. Araújo PEM. Historian. Personal communication. 2016 May $22^{\text {nd }}$.

25. Calógeras JP. A Fábrica de Ferro de São João de Ipanema. Revista Brasileira. 1895;1.

26. Gomes FAM. História da siderurgia no Brasil. São Paulo: EDUSP, 1983.
27. Alfonso-Goldfarb AM, Ferraz MHM. A institucionalização da metalurgia no Brasil: da Escola à Praxis. Revista da Sociedade Brasileira da História da Ciência. 1992;7:15-24.

28. Karsten CJB. Handbuch für Eisenhüttenkunde. Berlin: Reimer; 1841.

29. Tunner P. Die Stabeisen- und Stahlbereitung in Frischherden, oder, der Wohlunterrichtete Hammermeister. Freiberg: Engelhardt; 1858.

30. Landgraf FJG, Araújo PEM. A arquitetura do alto-forno e a biblioteca perdida de Ipanema: técnica e conhecimento no Brasil Joanino. In: Anais Eletrônicos do $14^{\circ}$ Seminário Nacional de História da Ciência e da Tecnologia; 2012 Out 8 - 11; Belo Horizonte, MG, Brasil. p. 1-15.

31. Relatório da Diretoria da Companhia Paulista. Document available at the library of the Museu da Companhia Paulista, Jundiaí, Brazil; 1883.

32. Wayman ML. Archaeometallurgical contributions to a better understanding of the past. Materials Characterization. 2000;45(4-5):259-267.

33. Piaskowski J. Metallographic investigations of ancient iron objects from the territory between the Oder and the basin of the Vistula River. The Journal of the Iron and Steel Institute. 1961;98:263-282.

34. Williams AR. Slag inclusions in armour. Journal of Historical Metallurgical Society. 1991;24:69-80.

35. Boniardi M, Gariboldi E, Vedani M. Metallographic studies on an ancient Roman nail. Metallurgical Science and Technology. 1992;10:28-38.

36. Pense AW. Iron through the ages. Materials Characterization. 2000;45(4-5):353-363.

37. Light JD. Observations concerning the hand forging of wrought iron. Materials Characterization. 2000;45(4-5):327-340.

38. Ehrhardt KL, Nash SK, Swann CP. Metal-forming practices among the seventeenth century Illinois, 1640-1682. Materials Characterization. 2000;45(4-5):275-288.

39. Jakielski KE, Notis MR. The metallurgy of Roman medical instruments. Materials Characterization. 2000;45(4-5):379-389.

40. Angelini E, Grassini S, Solorzano G, Campos GN, de Caro T. Integrated approach to the characterization of artifacts of the Brazilian colonial period. Applied Physics A, Materials Science \& Processing. 2006;83(4):485-491.

41. Campos GN, Solorzano GI. Microanalytical study of a ferrous agricultural tool recovered from a historical site in Rio de Janeiro. Applied Physics A, Materials Science \& Processing. 2004;79(2):315-318. 